\title{
CAMPAIGN FINANCE IN COMPARATIVE \\ PERSPECTIVE: A NESTED ANALYSIS APPROACH
}

Dalson Britto Figueredo Filho

Professor at the Federal University of Parnambuco, Brazil.

Ranulfo Paranhos

Professor at the Federal University of Alagoas, Brazil.

Enivaldo Carvalho da Rocha

Professor at the Federal University of Parnambuco, Brazil.

José Alexandre da Silva Júnior

Professor at the Federal University of Alagoas, Brazil.

Dinheiro compra tudo, até amor verdadeiro. Nelson Rodrigues

\begin{abstract}
This paper analyzes campaign finance in a comparative perspective, giving special attention to Brazil and the Unites States. The focus regards the level of regulation on the sources of campaign contributions. Methodologically, the research design adopts a nested approach, combining descriptive and multivariate statistics with deep case studies and documental analysis. Additionally, we replicate data from the Institute for Democracy and Electoral Assistance (IDEA) to estimate a standardized measure of regulation. The results suggest that most countries show low levels of control over the sources of campaign contributions. However, both Brazil and the United States display high levels of regulation on campaign finance, despite their widely different institutional designs.
\end{abstract}

Keywords: Campaign contributions - Regulation - Comparative law. 


\section{INTRODUCTION}

Imagine the following situations: (1) an election where candidates provide both food and beverages (including alcoholic) for voters just before they cast their votes; (2) a public service system where jobs are assigned by political criteria and 3) an incumbent candidate is charged of receiving campaign contributions in exchange for making favors for state contractors. These cases are not about Latin American countries that are well known by lack of law enforcement. These cases are not about African nations that are worldwide acknowledged by high levels of corruption. These cases represent both the U.S. (cases 1 and 2) and Canada (case 3 ) before regulating their campaign finance ${ }^{1}$.

Theoretically, campaign finance regulation aims to achieve two objectives: the promotion of political equality, and the prevention of corruption (SMITH, 2001) ${ }^{2}$. Arguments that favor increasing regulation are based on four assumptions: a) too much money is spent on political activity ${ }^{3}$; b) campaigns funded with large contributions are not representative of public opinion but biased toward big donors; c) a candidate's spending largely determines electoral results and d) money exerts a powerful corrupting influence on the legislature.

How does campaign finance regulation varies across countries? The main purpose of paper is to analyze campaign finance regulation in a comparative perspective, giving special attention to Brazil and the United States. The focus regards the level of regulation on the sources of campaign contributions. Methodologically, the research design adopts nested analysis technique, combining descriptive and multivariate statistics with deep case studies and documental analysis (legislation and jurisprudence). In addition, we replicate data from the Institute for Democracy and Electoral Assistance (IDEA) to estimate a standardized measure of regulation. The results suggest that most countries show limited levels of campaign finance regulation. Nevertheless, both Brazil

1 According to Smith (2001), in 1757, George Washington spent $£ 39$ to buy food and rum for his voters.

2 According to Ansolabehere (2007), the primary objective of campaign finance regulations is to prevent political corruption. Limits on contributions and expenditures aim to restrict both the supply and demand for political donations, thereby reducing or perhaps eliminating altogether the influence of donors and the private interests that they represent over publicly elected officials (ANSOLABEHERE, 2007: 163).

3 Respecting the increasing costs of elections, Ansolabehere, Gerber and Snyder (2001) point out that total expenditures in the average contested House election were $\$ 318,000$ in 1972 , $\$ 735,000$ in 1992, and $\$ 973,000$ in 2000 (all figures in 1990 dollars). Similarly, Jensen and Beyle (2003) argue that the costs of gubernatorial campaigns have been rising since 1968 . Abrams and Settle (1976) demonstrate that the costs of presidential elections also follow this same pattern. 
and the United States display high levels of control over the sources of campaign contributions, despite their widely different institutional designs.

The remainder of the paper is divided as follows. Next section reviews the literature on campaign spending and election outcomes. Section 3 describes data and methods. Section 4 presents the empirical results. Section 5 examines the historical development of campaign finance legislation in Brazil and in the United States. Section 6 summarizes the main conclusions.

\section{BRIEF LITERATURE REVIEW ${ }^{4}$}

The relationship between campaign spending and electoral outcomes is a canonical issue in Political Science (PALDA, 1973, 1975; WELCH, 1974, 1980; JACOBSON, 1976, 1978, 1985, 1990, 2001; SHEPARD, 1977; GLANTZ, ABROMOWITZ and BURKHART, 1976; ABROMOWITZ, 1988, 1991; GREEN and KRASNO, 1988, 1990; GERBER, 1998, 2004; BARDWELL, 2005). The typical research design regarding the effects of money on votes has three main characteristics: (1) it estimates a regression of a candidate's vote share on some function of the candidate's spending levels after controlling for additional variables; (2) it uses ordinary least squares functional form ${ }^{5}$; (3) the unit of analysis is the United States House of Representatives. According to Gerber (2004), the basic model to analyze the relationship between money and votes is the following:

$$
\text { Votes }_{\text {inc }}=\alpha+\beta_{1} f\left(\text { spendingi }_{n c}\right)+\beta_{2} f\left(\text { spending }_{\text {chal }}\right)+\beta_{3}(X)+\varepsilon
$$

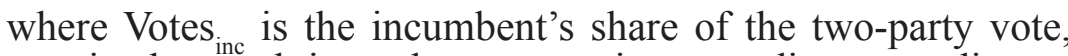
spending $_{\text {inc }}$ is the total incumbent campaign spending, spending chal $_{\text {, }}$ is the total challenger campaign spending, and $X$ represents a set of variables other than campaign spending that are thought to influence candidate election outcomes, such as challenger quality or constituency partisanship (GERBER, 2004).

Some scholars examine municipal elections (FLEISCHMANN and STEIN, 1998), subnational legislative (OWENS and OLSON, 1977; GILES and PRITCHARD, 1985; TUCKER and WEBER, 1987; JEWELL and BREAUX, 1988; HUDSON, 2006; BROWN, 2009), state primaries (BREAUX and GIERZYNSKI, 1991; HOGAN, 1999),

4 Jacobson (1985) reviews the empirical literature produced during the mid-1980s.

5 Regarding functional form, Welch (1974), Jacobson (1976) and Shepard (1977) employed linear models. Welch (1976) used a semi-log model, Lott e Warner (1974) used a log-log model and Silberman and Yochum (1978) employed a quadratic model. 
the Senate elections (GRIER, 1989; GERBER, 1998), gubernatorial races (PATTERSON, 1982; PARTIN, 2002; BARDWELL, 2005) and presidential nomination campaigns (HAYNES, GURIAN and NICHOLS, 1997). On methodological grounds, some pundits employ two-stage least squares (GREEN and KRASNO, 1988), logarithmic transformations (JACOBSON, 1978), computational experiments (HOUSER and STRATMANN, 2008), field experiments (Gerber and Green, 2000; Gerber, 2004) and natural experiments (MILYO, 1998) trying to properly identify the mechanisms that link spending and votes. On theoretical grounds, Gary Jacobson has produced the seminal work on campaign-spending literature ${ }^{6}$. Figure 1 illustrates the Jacobson`s effect.

Figure 1 - The Jacobson`s effect

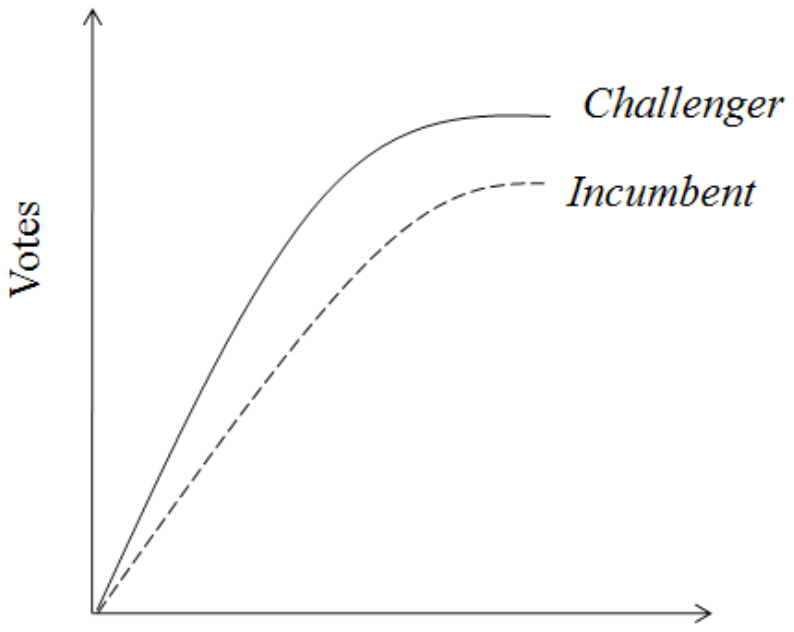

\section{Campaign spending}

Both challengers' and incumbents' spending exert a positive effect on their share of votes and suffer from diminishing returns. However, each extra dollar spent by challengers has a higher impact

6 According to Gerber (2004), "a common critique of Jacobson's findings was that incumbents raise their spending levels in response to strong threats. If the control variables do not fully account for the threat level, candidate spending effects will tend to be biased downward due to a negative correlation between incumbent spending and the regression error" (GERBER, 2004: 542). 
compared to incumbents spending ${ }^{7}$.

Levitt (1994) argues that campaign spending has an extremely small impact on election outcomes, regardless of who does the spending (LEVITT, 1994: 777). Gerber (1998) points out when the endogeneity of candidate spending levels is properly taken into account, the marginal effects of incumbent and challenger spending are roughly equal (GERBER, 1998: 401). Jacobson (1990) argues that

the ordinary least squares (OLS) regression models reported in most studies are inappropriate for estimating reciprocal relationships; a simultaneous equation system is required. OLS estimates of parameters when the true relationship is reciprocal are biased and inconsistent because endogenous variables (those which have a reciprocal effect on one another), when treated as explanatory variables, are correlated with the error term (JACOBSON, 1978: 470).

Nevertheless, there are controversial findings even among studies that employ two-stage least squares regression. For example, Green and Krasno (1988) reported that incumbent campaign spending coefficients' were positive and statistically significant. On the other side, Jacobson (1978) argued that spending by challengers has a much more substantial effect on the outcome of the election even with simultaneity bias purged from the equation (JACOBSON, 1978: 475). Figure 2 summarizes part of campaign spending literature.

Figure 2 - Literature summary

\begin{tabular}{l|l}
\hline \hline \multicolumn{1}{c|}{ Author (year) } & \multicolumn{1}{c}{ Argument } \\
\hline $\begin{array}{l}\text { Jacobson (1978); Abromowitz, (1988); } \\
\text { Ansolabehere e Gerber, (1994); Gerber(2004) }\end{array}$ & $\begin{array}{l}\text { Incumbent spending is ineffective but that } \\
\text { challenger spending produces large gains }\end{array}$ \\
\hline $\begin{array}{l}\text { Erikson e Palfrey (2000); Green e Krasno (1988); } \\
\text { Gerber (1998); Levitt (1994) }\end{array}$ & $\begin{array}{l}\text { Neither incumbent nor challenger spending makes } \\
\text { any appreciable difference }\end{array}$ \\
\hline $\begin{array}{l}\text { Kenny e McBurnett (1994); Goidel e Gross (1994); } \\
\text { Green e Krasno (1990) }\end{array}$ & $\begin{array}{l}\text { After controlling for quality of challenger and } \\
\text { reciprocal causation, marginal effect of incumbent } \\
\text { spending is substantial }\end{array}$ \\
\hline Krasno, Green e Cowden (1994) & $\begin{array}{l}\text { Incumbent spending is reactive to challenger } \\
\text { spending }\end{array}$ \\
\hline
\end{tabular}

7 Normatively, campaign spending limits will favor status quo. According to Jacobson (1978), any reform measure, which decreases spending by the candidates will favor incumbents. This includes limits on campaign contributions from individuals and groups as well as ceilings on total spending by the candidates (JACOBSON, 1978: 489). 
Despite scholarly efforts, comparative empirical work is still limited and our current understanding about campaign finance outside of the United States is scarce ${ }^{8}$. Thus, this paper aims to advance our existing knowledge on this subject by analyzing campaign finance regulation in a comparative perspective, giving special attention to Brazil and the United States. The focus regards the level of regulation on the sources of campaign contributions.

\section{DATA AND METHODS}

The research design adopts nested analysis approach, combining descriptive and multivariate statistics with deep case studies and documental analysis (legislation and jurisprudence). According to Lieberman (2005), nested analysis strategy improves the prospects of making valid causal inferences in cross-national and other forms of comparative research by drawing on the distinct strengths of two important approaches (LIEBERMAN, 2005: 435) ${ }^{9}$. The purpose is to take the most of each research technique.

\section{The importance of comparison}

Swanson (1971) argues that thinking without comparison is unthinkable. And in the absence of comparison, so is all scientific thought and scientific research (SWANSON, 1971). Lijphart (1971) defines the comparative method as one of the basic methods - the others being the experimental, statistical, and case study methods - of establishing general empirical propositions (LIJPHART, 1971: 682). And what are the advantages of a comparative research design? First, comparison allows one to estimate in what extent concepts can travel to analyze different social realities. Second, comparison permits one examine in what extent observed results can be reached under different institutional designs.

\section{Case selection}

Why to compare Brazil and the United States? First, most what we know about campaign finance was produced by U.S. scholars or/ and is about U.S. institutions. Second, both Tribunal Superior Eleitoral

8 Palda (1973; 1975), Eagles (1993), Carty and Eagles (1999) examine spending and votes in Canada. Johnston (1979) and Johnston, Pattie and Johnston (1989) analyze the England case. Epstein and Franck (2007) study the French elections. Samuels (2001a; 2001b; 2001c) has done pioneer work on campaign spending in Brazil. Fink (2011) estimates the effects of campaign spending in Germany.

9 To get more information on nested analysis see Lieberman (2005). To a seminal work on the comparative method see Lijphart (1971). To an introduction to case study methodology see Geddes (2003), Landman (2003) and Gerring (2004). 
(TSE) in Brazil and Federal Election Commission (FEC) in the United States provide open data on campaign finance, including datasets, specific legislation, learning environment, workshops, etc. Therefore, systematic disclosure of information facilitates comparison. Third, a comparative perspective between Brazil and the United States allows to understand how widely different institutional designs regulate campaign contributions. Figure 3 summarizes some institutional features in a comparative perspective.

Figure 3 - Institutional design features

\begin{tabular}{|c|c|c|}
\hline Feature & Brazil & United States \\
\hline Electoral system & Proportional & Majoritary \\
\hline Party system & Multiparty & Bipartisan \\
\hline District magnitude & $8-70$ & 1 \\
\hline Buy electioneering communication & No & Yes \\
\hline Direct corporation contribution & Yes & No \\
\hline
\end{tabular}

Besides the fundamental differences in their institutional designs (electoral system, party system and district magnitude), Brazil and the United States also differ on two important features regarding campaign finance. First, in Brazil, 9.504/97 federal law prohibits candidates and parties to buy any kind of electioneering communication (television, radio, newspapers, etc.) The amount of time available for parties and candidates depends upon the quantity of congressmen in the Legislature. Both party and candidate ads are broadcasted and the costs are paid by public resources. In the United States, candidates, Political Action Committees, parties and, independent groups can spend resources on electioneering communication ${ }^{10}$. Second, in Brazil, corporations can directly contribute to political candidates. In the United States, corporations contributions cannot flow directly to political campaigns, the procedure is indirect trough Political Action Committees (PACs) ${ }^{11}$.

10 The term electioneering communication means any broadcast, cable, or satellite communication which (I) refers to a clearly identified candidate for Federal office; (II) is made within 60 days before a general, special, or runoff election for the office sought by the candidate; or 30 days before a primary or preference election, or a convention or caucus of a political party that has authority to nominate a candidate, for the office sought by the candidate; and (III) in the case of a communication which refers to a candidate for an office other than President or Vice President, is targeted to the relevant electorate (§434(3)).

11 In Citizens United v. Federal Election Commission (2010), Supreme Court ruled that limitations on independent expenditures were unconstitutional, allowing both corporations and labor unions to spend unlimited amount of money to independently support or attack candidates. 
Variables description

According to King, Keohane and Verba (1994), the most important rule for all data collection is to report how the data were created and how we came to possess them (KING, KEOHANE and VERBA, 1994: 51). This is the core of scientific replicability ${ }^{12}$. Thus, it is important to briefly describe how variables were measured. Figure 4 summarizes this information.

Figure 4 - Variables

\begin{tabular}{|c|c|}
\hline Variable & Description \\
\hline $\mathrm{V}_{1}$ & Foreign entities \\
\hline $\mathrm{V}_{2}$ & Corporations \\
\hline $\mathrm{V}_{3}$ & State contractors \\
\hline $\mathrm{V}_{4}$ & Labor unions \\
\hline $\mathrm{V}_{5}$ & Anonymous \\
\hline
\end{tabular}

All variables are dummies. Each one informs if political actors can contribute to electoral campaigns. If contribution is prohibited variable assumes value 1 and zero otherwise. Data were originally collected by the Institute for Democracy and Electoral Assistance (IDEA)13.

\section{RESULTS}

Figure 5 - Contributions from foreign entities

\begin{tabular}{|c|c|c|}
\hline Foreign entities & $\mathbf{N}$ & \% (valid) \\
\hline Allowed & 73 & 64.00 \\
\hline Prohibited & 41 & 36.00 \\
\hline Total & $\mathbf{1 1 4}$ & $\mathbf{1 0 0 . 0}$ \\
\hline
\end{tabular}

Most countries allow contributions from foreign entities (64\%). Australia, Austria, Chile, Denmark, Finland, among others, display this institutional feature. However, 41 nations show some prohibition

12 King (1995) argues that the replication standard does not actually require anyone to replicate the results of an article or book. It only requires sufficient in-formation to be provided-in the article or book or in some other publicly accessible form-so that the results could in principle be replicated (KING, 1995: 444).

13 Raw data used here can be download at http://www.idea.int/parties/finance/db/index.cfm. A large dataset including variables used in this paper is available at http://www.qog.pol.gu.se/ 
regarding this type of campaign contributions (36\%). Argentina, Estonia, France, Israel and Poland are examples of countries that made this institutional choice. The 9.504/97 Brazilian statute prohibits both parties and candidates to receive, directly or indirectly, contributions or anything of value, including any kind of media support, from foreign entities (24, I, 9.504/97). Similarly, according to the Federal Election Commission, it shall be unlawful for a foreign national, directly or indirectly, to make a contribution or donation of money or other thing of value, or to make an express or implied promise to make a contribution or donation, in connection with a Federal, State, or local election ${ }^{14}$. It is also illegal to foreign nationals to make contributions or donations to political party committees. Finally, it is unlawful to foreign nationals make independent expenditures or disbursement for electioneering communication $(\$ 441 \mathrm{e})$. On substantive grounds, the prohibition of this type of contribution aims to prevent foreign political actors from influencing electoral outcomes.

Figure 6 - Contributions from corporations

\begin{tabular}{|c|c|c|}
\hline Corporations & $\mathbf{N}$ & \% (valid) \\
\hline Allowed & 94 & 81.70 \\
\hline Prohibited & 21 & 18.30 \\
\hline Total & $\mathbf{1 1 5}$ & $\mathbf{1 0 0 . 0}$ \\
\hline
\end{tabular}

Regarding contributions from corporations, most countries allow this type of donation (81.70\%). Ireland, Italy, Jamaica, Japan, among others, show this institutional feature. Only $18.30 \%$ of nations have some express prohibition on corporate campaign contributions. Portugal, Bolivia, Belgium, Hungary, among others, made this institutional choice. In Brazil, corporations can directly contribute to political campaigns up to $2 \%$ of their annual gross revenue $\left(81, \S 1^{\circ}\right.$, 9.504/97). If donations exceed the legal ceiling, there is a penalty of five times the amount exceeded $\left(81, \S 2^{\circ}, 9.504 / 97\right)$. In the United States, Tillman Act (1907) ban direct contributions from corporations. Current legislation makes unlawful for any national bank, or any corporation organized by authority of any law of Congress, to make a contribution or expenditure in connection with any election to any political office, or in connection with any primary election or political convention

14 Historically, the ban on political contributions and expenditures by foreign nationals was first enacted in 1966 as part of the amendments to the Foreign Agents Registration Act (FARA). The goal of the FARA was to minimize foreign intervention in U.S. elections by establishing a series of limitations on foreign nationals. 
or caucus held to select candidates for any political office ${ }^{15}$ (§ 441b). Normatively, prohibitions on corporate contributions aim to prevent disproportional influence of corporate sector on policymaking process.

Figure 7 - Contributions from state contractors

\begin{tabular}{|c|c|c|}
\hline State contractors & $\mathbf{N}$ & \% (valid) \\
\hline Allowed & 86 & 76.10 \\
\hline Prohibited & 27 & 23.90 \\
\hline Total & $\mathbf{1 1 3}$ & $\mathbf{1 0 0 . 0}$ \\
\hline
\end{tabular}

Most countries allow contributions from state contractors (76.10\%). Chile, Singapore, Russia, United Kingdom, among others, share this institutional feature. Only $23.90 \%$ countries have express prohibition statutes on state contractors' contributions. Czech Republic, Paraguay, Spain, Burkina Faso, among others, adopted this type of ban. In Brazil, national statute 9.504/97 prohibits contributions from state contractors (81, III, 9.504/97). Similarly, in the United States, contributions from state contractors are unlawful (§ 441c). On substantive grounds, this type of prohibition aim to prevent exchange of campaign contributions for governmental contracts benefits.

Figure 8 - Contributions from Labor unions

\begin{tabular}{|c|c|c|}
\hline Labor unions & $\mathbf{N}$ & \% (valid) \\
\hline Allowed & 98 & 85.20 \\
\hline Prohibited & 17 & 14.80 \\
\hline Total & $\mathbf{1 1 5}$ & $\mathbf{1 0 0 , 0}$ \\
\hline
\end{tabular}

Following the trend of less regulation, most countries allow donations from labor unions (85.20\%). Belgium, Czech Republic, Mexico, Bolivia, among others, show this institutional feature. Only $14.80 \%$ of the cases prohibit this type of campaign contributions. Guatemala, Portugal, Azerbaijan, Poland, among others, adopted this kind of ban. In Brazil, statute 9.504/97 excludes labor unions from contributing to political campaigns (24, VI, 9.504/97). In the United States, Smith-Connally Act (1943) temporarily prohibited contributions from labor unions. In 1947, Congress enacted Labor Management Relations Act (Taft-Hartley Act) banning labor donations ever since. The current legislation includes Labor contributions in the same section of national banks and corporations $(\$ 441 b)$.

15 See Corrado (2005) for more details on indirect contributions. 
Campaign Finance - Paranhos, Fiqueiredo Filho, Rocha and Silva Júnior

Figure 9 - Anonymous Contributions

\begin{tabular}{|c|c|c|}
\hline Anonymous & N & \% (valid) \\
\hline Allowed & 66 & 58.40 \\
\hline Prohibited & 47 & 41.60 \\
\hline Total & $\mathbf{1 1 3}$ & $\mathbf{1 0 0 , 0}$ \\
\hline
\end{tabular}

$58.40 \%$ of all countries allow anonymous campaign contributions. Paraguay, Iceland, New Zealand, Sweden, among others, show this institutional choice. However, $41.60 \%$ of the sample ban this type of contribution. Argentina, France, Belgium, Bulgaria, among others, have this institutional feature. In Brazil, Tribunal Superior Eleitoral $23.217 / 10$ resolution made mandatory to both party and candidates to fully disclose information on their campaign sources, indicating both the name and origin of campaign contributions $\left(14,1^{\circ}, \mathrm{I}\right.$, resolution 23.217/10). In the United States, according to the Federal Election Commission, anonymous campaign contributions are permitted up to $\$ 50,00$. On substantive grounds, ban on this type of contribution aim to guarantee electoral system transparency.

Finally, we estimate two measures of campaign finance regulation. The first one is just the sum of all above variables. Mathematically, the index varies from 0 to 5 and its interpretation is forward: the higher its magnitude, more regulation on campaign finance system. Value zero means that all contributions are allowed. Value 5 means that all contributions are prohibited. The second measure was based on a principal component analysis (PCA). This technique summarizes shared variance of observed variables in few standardized components. The model reached the following results: a) Kaiser-Meyer-Olkin test of sample adequacy of .751 ; b) Bartlett test of sphericity significant at .000 ; and c) $53.11 \%$ of cumulative variance. The Pearson correlation between the raw regulation index and the standardized measure reached .997 ( $\mathrm{p}$-value <.000). On substantive grounds, the strong correlation suggests that both index are measuring the same phenomena. Figure 10 summarizes descriptive statistics.

Figure 10 - Descriptive statistics

\begin{tabular}{|c|c|c|c|c|c|}
\hline Regulation Measure & $\mathbf{N}$ & $\mathbf{m i n}$ & $\mathbf{m a x}$ & mean & std \\
\hline Raw & 112 & 0 & 5 & 1,36 & 1,57 \\
\hline Standardized & 112 & .82 & 2,39 & 0 & 1 \\
\hline
\end{tabular}

On one hand, some countries have very deregulated system, 
allowing all types of campaign contributions (Austria, Barbados, Denmark, Finland, New Zealand, Norway, among others). On the other hand, some nations display maximum control over campaign contributions sources (Argentina, Estonia, France, Portugal, United States, among others). On average, the raw measure of regulation suggests that 1.36 up to five bans are adopted for most countries. The standard deviation is higher than the mean, suggesting elevated distribution spread. Figure 11 displays regulation index in selected countries.

Figure 11 - Standardized measure of regulation

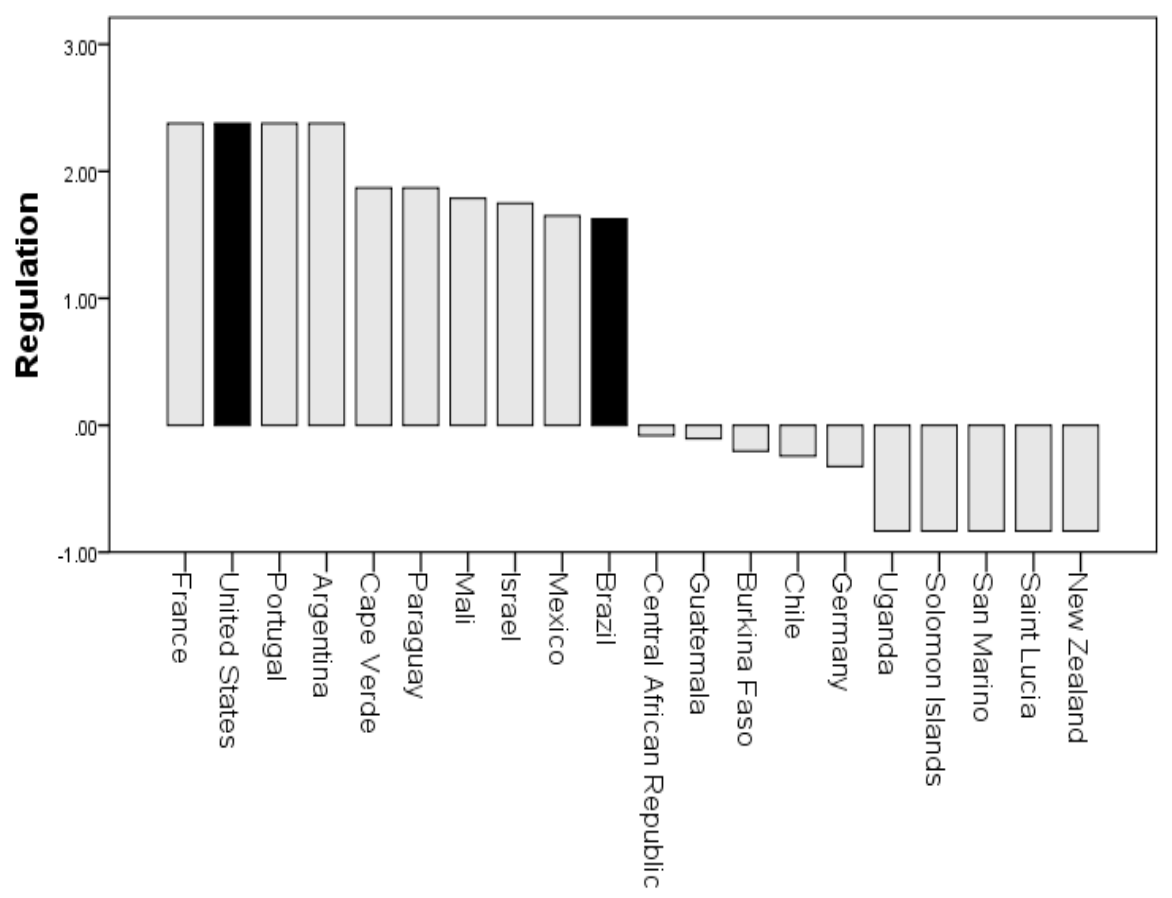

For the standardized measure, the mean is 0 and the standard deviation is 1 . As far from the mean in the positive direction, more regulation. As far from the mean on the negative direction, less regulation. While France, United States, Portugal and Argentina display maximum level of regulation, New Zealand, Saint Lucia, San Marino and Solomon Islands show a very deregulated system. Figure 12 presents a comparison between Brazil and United States bans on campaign contributions sources. 
Campaign Finance - Paranhos, Fiqueiredo Filho, Rocha and Silva Júnior

Figure 12 - Ban on campaign contributions

\begin{tabular}{|c|c|c|}
\hline Sources & Brazil & United States \\
\hline Foreign entities & $\mathrm{X}$ & $\mathrm{X}$ \\
\hline Corporations & -- & $\mathrm{X}$ \\
\hline State contractors & $\mathrm{X}$ & $\mathrm{X}$ \\
\hline Labor unions & $\mathrm{X}$ & $\mathrm{X}$ \\
\hline Anonymous & $\mathrm{X}$ & $\mathrm{X}$ \\
\hline
\end{tabular}

\section{BRAZIL AND THE UNITED STATES IN A COMPARATIVE PERSPECTIVE}

This section examines the historical development of campaign finance in Brazil and the United States. The focus regards the level of regulation on the sources of campaign contributions on both statutes and jurisprudence.

\section{Campaign finance in Brazil}

According to Backes (2001), despite different statues on elections, there is no legal document respecting campaign finance during Brazil Empire period (1822-1889). Regarding popular inclusion, legislation was very restrictive since it required a minimum annual income as formal criteria to allow people the right to vote ${ }^{16}$. Therefore, a very limited amount of people was able to participate in the electoral process. 6 National Statute (1889) ban voto censitário in Brazil but electoral participation continued limited since legislation prohibited both illiterate people and women the right to vote. During Brazilian Estado Novo (New State, 1930-1945), different institutional changes were adopted: 1) proportional representation for the House of Representatives; 2) creation of Electoral Justice and 3) women right to vote. Despite these innovations, Brazilian 1934 Constitution and further legislation did not addressed the financing of elections (BACKES, 2001). In short, during two important periods of the Brazilian history -- Empire and New State -- there was no specific legislation regarding campaign finance.

It was during the first democratic period (1946-1964) that campaign finance became an issue. Two elements are important to

16 It was called voto censitário and required annual income higher than 100.000 Reis to vote for municipal elections - Assembleias Parochiais (92, V), 200.000 Reis to vote for the House of Representatives and Senate elections (94, I) and 400.000 Reis to run for an election office $(95, \mathrm{I})$. 
understand this shift. First, the adoption of direct vote for presidential elections. Second, the increase on electorate size. Regarding regulation, 9.258/46 and 1.164/50 National Statutes established a new Electoral Code. In particular, chapter V defined: a) spending limits (143); b) ban on foreign contributions (144, I) and c) prohibition of public contractors to contribute to political campaigns $(144, \text { III })^{17}$. Statutes 4.740/65 and 5.682/71 are also important to understand the Brazilian campaign finance historical legislation. They ban contributions from corporate sector for the first time. In particular, section 56 of 4.740 statute prohibited political parties to receive, directly or indirectly, any kind of resource from corporations. Section 91 of 5.682 statute also ban contributions from labor unions. Currently, campaign finance in Brazil is mainly based on three different statutes (9.096/95, 9.504/97 and 11.300/06), in addition to Tribunal Superior Eleitoral resolutions ${ }^{18}$. Section 23 of 9.504 statute limits individual contributions to $10 \%$ of donors' annual gross income previous to electoral year. Regarding own resources, political parties should stipulate the maximum amount that each candidate can spend before elections starts $(\S 23,1)$. In practice, this means that there is no legal ceiling since parties have discretion to set up any limit. Section 81 limits corporate contributions to $2 \%$ of donors' annual gross revenue previous to electoral year. What to say about other sources of campaign contributions? Figure 13 summarizes all prohibited sources.

Figure 13 - Prohibited sources by 9.504/97 statute

\begin{tabular}{|c|c|}
\hline Section & Source \\
\hline I & Foreign entities \\
\hline II & Administrative public institutions \\
\hline III & State contractors \\
\hline IV & Nonprofit organizations \\
\hline V & Labor unions \\
\hline VI & Nonprofit organizations funded by foreign entities \\
\hline VII & Charitable and religious organizations \\
\hline VIII & Sports organizations \\
\hline IX & Nongovernment organizations funded by public resources \\
\hline X & Civil society organizations \\
\hline
\end{tabular}

17 Resolution 3.988 (1950) determined that both the Tribunal Superior Eleitoral (TSE) and state level agencies (Tribunais Regionais Eleitorais - TREs) could investigate claims of illegal electoral activities (BACKES, 2011).

18 For example, resolution 23.089 (2009) established electoral calendar. Resolution 23.217 (2010) regulates campaign finance receipts and disclosure for candidates and parties committees. 
Campaign Finance - Paranhos, Fiqueiredo Filho, Rocha and Silva Júnior

For the purposes of this paper it is important to evaluate how Brazilian campaign finance regulation changed over time. Figure 14 summarizes this information.

Figure 14 - Campaign finance legislation over time

\begin{tabular}{|c|c|c|c|c|c|c|c|c|c|c|}
\hline Source & 1946 & 1950 & 1965 & 1971 & 1993 & 1995 & 1997 & 2006 & 2008 & 2010 \\
\hline Foreign entities & X & X & X & X & X & X & X & X & X & X \\
\hline Administrative public institutions & & X & X & X & X & X & X & X & X & X \\
\hline State contractors & & X & X & X & X & X & X & X & X & X \\
\hline Corporations & & & X & X & & & & & & \\
\hline Non-profit organizations & & & & & X & & X & X & X & X \\
\hline Labor unions & & & & X & X & X & X & X & X & X \\
\hline Non-profit organizations funded by foreign entities & & & & & X & & X & X & X & X \\
\hline Charitable and religious organizations & & & & & & & & X & X & X \\
\hline Sports organizations & & & & & & & & X & X & X \\
\hline Non-government organizations funded by public resources & & & & & & & & X & X & X \\
\hline Civil society organizations & & & & & & & & X & X & X \\
\hline
\end{tabular}

Contributions from foreign entities had been banned by all Brazilian campaign finance legislation. Since 1950, administrative public institutions and state contractors also were prohibited from making donations. Regarding corporations contributions, both 1965 and 1971 legislation ban it but posterior statutes make it legal. More recently, new political actors were prohibited from making campaign contributions (charitable and religious organizations, sport organizations, nongovernment organizations funded by public resources and civil society organizations). On substantive grounds, this means that regulation on campaign finance has increased over time.

\section{Campaign finance in the United States ${ }^{19}$}

As Brazil during Empire period, the financing of elections was not a problem during the early days of American politics (CORRADO, 2005; SMITH, 2001). According to Corrado (2005),

in the early days of the republic, campaign funding was rarely a source of public controversy (...) since candidates usually "stood" for election without engaging in the types of personal politicking

19 The most comprehensive compilation of campaign finance regulation in the United States can be download at http://www.fec.gov/law/feca/feca.pdf 
or direct solicitation of votes that have come to characterize modern elections (CORRADO, 2005: 07/08).

Smith (2001) points out that before the Pendleton Civil Service Act (1883) most of public offices were not elected and candidates run without opponents. Candidates use their own resources or contributions of family and friends to cover campaign costs. It was with spoils system that campaign finance became an issue in the United States. In particular, Congress enacted the Pendleton Civil Service Act (1883) determining meritocratic criteria to public employees selection process ${ }^{20}$. According to Corrado (2005),

the law restrained the influence of the spoils system in the selection of government workers by creating a class of federal employees who had to qualify for office through competitive examinations. It also prohibited the solicitation of political contributions from those employees, thus protecting them from forced campaign assessments (CORRADO, 2005: 9/10).

In 1904, judge Alton B. Parker, the Democratic presidential nominee, charged Theodore Roosevelt of exchanging political favors for campaign contributions (Corrado, 2005). Parker also alleged that Roosevelt was blackmailing corporation monopolies to raise campaign contributions. According to Smith (2001), more than 73\% of all Republican general committee resources in 1904 were based on corporate contributions. Roosevelt denied all charges. However, a joint investigation of two different New York committees revealed that New York Life contributed with near to $\$ 48,000$ for an non-registered account of the Republican National Party Committee in $1904^{21}$. Since 1890, Nebraska, Missouri, Tennessee and Florida banned corporate contributions to state elections, but after New York Life scandal public opinion demand more regulation. In 1907 Congress enacted Tillman Act.

In 1924, public demand for more regulation arose again after a scandal involving campaign contributions to incumbents candidates

20 Also in 1883 United Kingdom enacted the Corrupt and Illegal Practices Prevention Act. Among its provisions, it made a crime to exchange votes for any economic benefit. In addition, the act imposed campaign spending limits.

21 In 1905 message to the Congress president Roosevelt stated that there is no enemy of free government more dangerous and none so insidious as the corruption of the electorate (...) I recommend the enactment of a law directed against bribery and corruption in Federal elections. 
in a non-electoral year. Congress passed new amendments to Federal Corrupt Practices Act (1910), requiring that any contribution over \$ 100,00 must be registered under party disclosure documents. In addition, it established new ceilings for spending for both House $(\$ 5,000)$ and senate elections $(\$ 25,000)$. This act constituted a landmark on campaign finance until the $1970 \mathrm{~s}^{22}$.

In 1947, Congress ban Labor unions campaign contributions under Labor Management Relations Act (1947), popular knew as TaftHartley Act. In 1971, Congress enacted Federal Election Campaign Act (FECA). According to Smith (2001), it aimed to accomplish the following objectives: a) enforce disclosure provisions by adopting specific punishments for law break; b) increase the amount of resources available to public financing of presidential elections; c) establish ceilings on campaign spending, and d) decrease the general costs of elections. FECA (1971) assumed that the increasing costs of elections were direct associated with spending on media communications. In particular, the 1974 FECA amendments limited spending on media to no more than $\$ 100,000$ or $\$ .08$ multiplied by the voting-age population of the state in a primary election and no more than $\$ 150,000$ or $\$ .12$ multiplied by the state's voting-age population in a general election. However, before Congress enacts FECA general costs of 1968 were estimated around \$ 300 million, compared to \$425 million of 1972 elections ${ }^{23}$.

In 1974 Congress enacted amendments to FECA (1971) establishing the most comprehensive regulatory package on campaign finance. Individual limits were defined to $\$ 1,000$ and up tp $\$ 25,000$ during electoral calendar year. PCAs contributions were also limited to $\$ 5,000$. Among different institutional reforms, FECA 1974 amendments established the Federal Election Commission (Corrado, 2005). However, in Buckley v. Valeo, Supreme Court struck down most FECA provisions ruling that they infringe the First Amendment ${ }^{24}$. Supreme Court ruled that while campaign expenditures by individual candidate

22 According to Corrado (2005), despite the changes, an effective regulatory regime was never established. Though the law imposed clear reporting requirements, it provided for none of the publicity or enforcement mechanisms needed to ensure meaningful disclosure. The law did not specify who would have access to the reports; it did not require that the reports be published; it did not even stipulate the penalties if committees failed to comply. As a result, many candidates did not file regular reports (CORRADO, 2005: 15).

23 For example, president Richard Nixon spent more than twice in 1972 compared to 1968. Democrat George McGovern spent more than four times the total spent in 1968.

24 Congress shall make no law respecting an establishment of religion, or prohibiting the free exercise thereof; of abridging the freedom of speech, or of the press; of the right of the people peaceably to assemble, and to petition the Government for a redress of grievances (Amendment I, U.S. Constitution) 
is speech and therefore cannot be regulated, campaign contributions do not constitute a form of direct speech and thus could be regulated. The rationale to differentiate expenditures from campaign contributions was to prevent the corruption or appearance of corruption associated with large donations.

a restriction on the amount of money a person or group can spend on political communication during a campaign necessarily reduces the quantity of expression by restricting the number of issues discussed, the depth of their exploration, and the size of the audience reached. This is because virtually every means of communicating ideas in today's mass society requires the expenditure of money (...) the electorate's increasing dependence on television, radio, and other mass media for news and information has made these expensive models of communication indispensable instruments of effective political speech (...) being free to engage in unlimited political expression subject to a ceiling on expenditures is like being free to drive an automobile as far and as often one desires on a single tank of gasoline (...) although the Act 's contribution and expenditure limitations both implicate fundamental First Amendment interests, its expenditure ceilings impose significantly more severe restrictions on protected freedoms of political expression and association than do its limitations on financial contributions (...) the increasing importance of the communications media and sophisticated mass-mailing and polling operations to effective campaigning make the raising of large sums of money an ever more essential ingredient of an effective candidacy (...) ceilings were a necessary legislative concomitant to deal with the reality or appearance of corruption (Buckley v. Valeo, 1976).

.In McConnell v. Federal Election Commission (2002), Supreme Court upheld the constitutionality of most provisions of Bipartisan Campaign Reform Act (BCRA -- 2002). The Court ruled that the ban on soft money imposed only minimal effects on speech and corporations could not employ their treasury funds to pay or broadcast express advertisements targeted to the candidate's electorate within 
30 days of a primary or 60 days of a general election ${ }^{25}$. In Federal Election Commission v. Wisconsin Right to Life, Inc. (2007), Supreme Court held $\$ 203$ of the BCRA unconstitutional as applied to political advertisements that criticized Wisconsin's senators for participating in a filibuster to block the confirmation of several of President Bush's judicial nominees. According to the FEC, the Supreme Court concluded that these financing restrictions are unconstitutional as applied to these ads because the ads were not express advocacy or its "functional equivalent". More recently, in Citizens United v. Federal Election Commission (2010), Supreme Court held that corporate funding of independent political broadcasts in candidate elections cannot be limited because infringes the First Amendment. In particular, the Court considered that Sections 201 and 203 of Bipartisan Campaign Reform Act (BCRA) were unconstitutional ${ }^{26}$. This decision overturned the prohibition of both corporate and labor free spending to independently support or oppose candidates in national elections.

Although the First Amendment provides that "Congress shall make no law... abridging the freedom of speech," \$441b's prohibition on corporate independent expenditures is an outright ban on speech, backed by criminal sanctions. It is a ban notwithstanding the fact that a PAC created by a corporation can still speak, for a PAC is a separate association from the corporation. Because speech is an essential mechanism of democracy--it is the means to hold officials accountable to the people---political speech must prevail against laws that would suppress it by design or inadvertence. Laws burdening such speech are subject to strict scrutiny, which requires the Government to prove that the restriction "furthers a compelling interest and is narrowly tailored to achieve that interest (...) It is irrelevant for First Amendment purposes that corporate funds may "have little or no correlation

25 Section 441i(a) of FEC states that A national committee of a political party (including a national congressional campaign committee of a political party) may not solicit, receive, or direct to another person a contribution, donation, or transfer of funds or any other thing of value, or spend any funds, that are not subject to the limitations, prohibitions, and reporting requirements of this Act.

26 Section 203 of (BCRA) prohibits corporations and unions from using their general treasury funds to make independent expenditures for speech that is an "electioneering communication" or for speech that expressly advocates the election or defeat of a candidate (Citizens United v. Federal Election Commission) 
to the public's support for the corporation's political ideas. " Austin, supra, at 660. All speakers, including individuals and the media, use money amassed from the economic marketplace to fund their speech, and the First Amendment protects the resulting speech. Under the antidistortion rationale, Congress could also ban political speech of media corporations.

Figure 15 provides a historical overview of regulatory provisions on campaign finance in the United States.

Figure 15 - Historical development of campaign finance regulation

\begin{tabular}{|c|l|}
\hline Regulation (year) & \multicolumn{1}{|c|}{ Purpose/provisions } \\
\hline Tillman Act (1907) & $\begin{array}{l}\text { Reduce the role of big contributions on federal } \\
\text { elections. It make illegal donations from corporations } \\
\text { and national banks. }\end{array}$ \\
\hline $\begin{array}{c}\text { Federal Corrupt Practices } \\
\text { Act (1910) (Publicity Act) }\end{array}$ & $\begin{array}{l}\text { Established disclosure provisions and spending } \\
\text { ceilings for the House of Representatives elections. }\end{array}$ \\
\hline $\begin{array}{c}\text { Federal Corrupt Practices } \\
\text { (1911) and (1925) } \\
\text { amendments }\end{array}$ & $\begin{array}{l}\text { Expanded disclosure provisions in national elections } \\
\text { by including Senate seats. Established new ceilings } \\
\text { on primary and general elections spending. }\end{array}$ \\
\hline $\begin{array}{c}\text { Hatch Act (1939) (Clean } \\
\text { Politics Act) }\end{array}$ & Reduce the political influence of federal employees. \\
\hline $\begin{array}{c}\text { Smith-Connaly Act (1943) } \\
\text { (War Labor Disputes Act) }\end{array}$ & Temporarily prohibited labor unions contributions. \\
\hline $\begin{array}{c}\text { Labor Management } \\
\text { Relations Act (1947) (Taft- } \\
\text { Harley Act) }\end{array}$ & $\begin{array}{l}\text { Ban both labor unions donations and independent } \\
\text { expenditures. }\end{array}$ \\
\hline $\begin{array}{c}\text { The Federal Election } \\
\text { Campaign Act (1971) }\end{array}$ & $\begin{array}{l}\text { Enforce disclosure provisions; extend public financing } \\
\text { of presidential elections; limit contributions and } \\
\text { spending; reduce the role of media communications } \\
\text { in elections }\end{array}$ \\
\hline $\begin{array}{c}\text { The Federal Election } \\
\text { Campaign Act (1974) } \\
\text { (amendments) }\end{array}$ & Established the Federal Election Commission \\
\hline $\begin{array}{c}\text { Bipartisan Campaign } \\
\text { Reform Act (2002) }\end{array}$ & $\begin{array}{l}\text { Ban soft money. Established new ceilings on } \\
\text { contributions limits. }\end{array}$ \\
\hline
\end{tabular}




\section{CONCLUSION}

The principal aim of this paper was to analyze campaign finance in a comparative perspective, giving special attention to cases of Brazil and the United States. The results suggest that most countries show low levels of control over campaign contributions. However, both Brazil and the United States display higher levels of regulation on campaign finance sources, despite their widely different institutional designs. On institutional grounds, both Tribunal Superior Eleitoral (TSE) and Federal Election Commission (FEC) provide public open data regarding campaign finance and elections outcomes. Assuming that institutional change can benefit from information about other institutional contexts, it is important to understand how different countries regulate the role of money in politics. Comparative perspective allows evaluate which institutional practices seem to be more efficient and which ones are more likely to work on different institutional designs.

Undeniably, one of main challenges faced not only by scholars but also by policymakers is to properly estimate the effects of electoral rules. This is because any attempt of political reform should be informed by the effects of each institutional choice. This paper aims to advance our current knowledge on campaign finance regulation in general and in both Brazil and in the United States in particular.

\section{REFERENCES}

ABRAMOWITZ, A. (1988), Explaining Senate election outcomes. American Political Science Review, 82, 385-403.

ABRAMOWITZ, A. (1991), Incumbency Campaign Spending, and the Decline of Competition in U.S. Elections. Journal of Politics, 53: 34-56.

ABRAMS, B. and SETTLE, R. (1976). The Effect of Broadcasting on Political Campaign Spending: An Empirical Investigation. Journal of Political Economy, 84, 5: 1095-1108.

ANSOLABEHERE, S. and GERBER, A. (1994), The Mismeasure of Campaign Spending: Evidence from the 1990 U.S. House Elections. Journal of Politics, 56: 1106-18.

ANSOLABEHERE, S. (2007), The Scope of Corruption: Lessons from Comparative Campaign Finance Disclosure. Election Law Journal, 6, 2: 163-183.

ANSOLABEHERE, S.; GERBER, A., and SNYDER, J. (2011), Does TV Advertising Explain the Rise of Campaign Spending? A Study of Campaign Spending and Broadcast Advertising Prices in US House Elections the 1990s and the 1970s. Working paper, 2001. Available at: http://econ-www.mit.edu/files/1211

BACKES, A. (2000), Legislação sobre financiamento de partidos e de 
campanhas eleitorais no Brazil em perspectiva histórica. Available at http://pdba.georgetown.edu/Parties/Brazil/Leyes/financiamento.pdf.

BARDWELL, K. (2005), Reevaluating Spending in Gubernatorial Races: Job Approval as a Baseline for Spending. Political Research Quarterly, 58, 1: 97-105.

BOURDOUKAN, A. (2010), O Bolso e a urna: financiamento de campanha em perspectiva comparada. Tese de Doutorado. Universidade de São Paulo. Departamento de Ciência Política.

BREAUX, D. and GIERZYNSKI, A. (1991), "It's Money That Matters": Campaign Expenditures and State Legislative Primaries. Legislative Studies Quarterly, 16, 3: 429-443.

BROWN, A. (2009), Campaign Spending and Spurious Correlations: Why Self-Financed Gubernatorial Candidates Lose. Prepared for presentation at the annual meeting of the American Political Science Association, held in Toronto, Canada, September 3-6.

BUCKLEY v. VALEO, 424, U.S. 1, 1976. Available at: http://www.law. cornell.edu/supct/html/historics/USSC_CR_0424_0001_ZS.html

CARTY, K. and EAGLES, M. (1999), Do local campaigns matter? Campaign spending, the local canvass and party support in Canada. Electoral Studies, 18: 69-87.

CITIZENS UNITED v. FEDERAL ELECTION COMMISSION (2010). Available at: http://www.law.cornell.edu/supct/html/08-205.ZS.html

CORRADO, A. (2005), "Public funding of presidential campaigns", In: A. Corrado, T. E. Mann, D. R. Ortiz e T. Potter (Eds.), The new campaign finance sourcebook (pp. 180--204). Washington, DC: Brookings Institution Press.

EAGLES, M. (1993), Money and Votes in Canada: Campaign Spending and Parliamentary Election Outcomes, 1984 and 1988. Canadian Public Policy/Analyse de Politiques, 19, 4: 432-449.

EPSTEIN, G. and FRANCK, R. (2007), Campaign Resources and Electoral Success: Evidence from the 2002 French Parliamentary Elections. Public Choice, 131, 3/4: 469-489.

ERIKSON, R. and PALFREY, T. (2000), Equilibria in campaign spending games: Theory and evidence. American Political Science Review, 94, 595609.

FINK, A. The effects of party campaign spending under proportional representation: evidence from Germany. Working paper. Available at: http://www.ub.edu/economiaempresa/jobmarket/papers/Alexander/ ApplicantFileView.pdf

FLEISCHMANN, A. and STEIN, L. (1998), Campaign Contributions in Local Elections. Political Research Quarterly, 51, 3: 673-689.

GEDDES, B. (2003), Paradigms and Sand Castles: Theory Building and Research Design in Comparative Politics. Ann Arbor: University of Michigan Press. 
GERBER, A. and GREEN, D. (2000), The effects of canvassing, telephone calls, and direct mail on voter turnout: A field experiment. American Political Science Review, 94, 653-663.

GERBER, A. (2004), Does Campaign Spending Work? Field Experiments Provide Evidence and Suggest New Theory. American Behavioral Scientist, 47(5), 541-574.

GERBER, A. (1998), Estimating the effect of campaign spending on Senate election outcomes using instrumental variables. American Political Science Review, 92, 401-411.

GERRING, J. (2004), What Is a Case Study and What Is It Good for? American Political Science Review, 98, 2: 341-354.

GILES, M. and PRITCHARD, A. (1985), Campaign Expenditures and Legislative Elections in Florida. Legislative Studies Quarterly, 10, 1: 7188.

GLANTZ, S.; ABRAMOWITZ, A., and BURKHART, M. (1976), Election Outcomes: Whose Money Matters? Journal of Politics, 38:10338.

GOIDEL, R. and GROSS, D. (1996), Reconsidering the 'Myths and Realities' of Campaign Finance Reform. Legislative Studies Quarterly, 21, 1: 129-149.

GREEN, D. and KRASNO, J. (1990), Rebuttal to Jacobson's New Evidence for Old arguments. American Journal of Political Science, 34: 363-72.

GREEN, D. and KRASNO, J.(1988), Salvation for the spendthrift incumbent. American Journal of Political Science, 32, 884-907.

GRIER, K. (1989), Campaign Spending and Senate Elections, 19781984. Public Choice, 63: 201-219.

HAYNES, A., GURIAN, P. and NICHOLS, S. (1997), The Role of Candidate Spending in Presidential Nomination Campaigns. The Journal of Politics, 59, 1: 213-225.

HOGAN, R. (1999)Campaign Spending in State Legislative Primary Elections. State and Local Government Review, 31, 3: 214: 220.

HOUSER, D. and STRATMANN, T. (2008), Selling Favors in the Lab: Experiments on Campaign Finance Reform. Public Choice,136: 215-239. HUDSON, R. The effects of campaign spending in Florida congressional elections. Working paper, 2006. Available at: http://web.bus.ucf.edu/faculty/rhofler/file. axd?file $=2011 \% 2$ F2\%2FHudson+Campaign+Spending.pdf

JACOBSON, G. (1985), Money and votes reconsidered: Congressional elections, 1972-1982. Public Choice, 47(1): 7-62.

JACOBSON, G. (1976), Public Funds for Congressional Candidates: Who Would Benefit? Public Policy, 24: 1-32.

JACOBSON, G. (1978), The effect of campaign spending in congressional elections. American Political Science Review, 72: 469-491. 
JACOBSON, G. (1990), The effects of campaign spending in House elections: New evidence for old arguments. American Journal of Political Science, 34: 334-362.

JACOBSON, G. (2001), The politics of congressional elections (5th ed.). New York: Longman.

JENSEN, J, and BEYLE, T. (2003), Of Footnotes, Missing Data, and Lessons for 50-State Data Collection: The Gubernatorial Campaign Finance Project, 1977-2001. State Politics and Policy Quarterly, 3:203214.

JEWELL, M. and BREAUX, D. (1988), The Effect of Incumbency on State Legislative Elections. Legislative Studies Quarterly, 13, 4: 495-514. JOHNSTON, R. (1979). Campaign expenditure and the efficacy of advertising at the 1974 general election in England. Political Studies, XXVII, 1: 114-119.

JOHNSTON, R., A, PATTIE and JOHNSTON, L. (1989), The impact of constituency spending on the result of the 1987 British General Election. Electoral Studies, 8, 2: 143-155.

KENNY, C. and MCBURNETT, M. (1994), An Individual-Level Multiequation Model of Expenditure Effects in Contested House Elections. American Political Science Review, 88, 3: 699-707.

KING, G. Replication, Replication. PS: Political Science and Politics, 28: 443-499, 1995.

KING, G.; KEOHANE, R. and VERBA, S. (1994), Designing social inquiry: scientific inference in qualitative research. Princeton: Princeton University Press.

KRASNO, J., GREEN, D. and COWDEN, J. (1994), The Dynamics of Campaign Fundraising in House Elections. Journal of Politics, 56: 45974.

LANDMAN, T. (2003), Issues and Methods in Comparative Politics: An Introduction, $2^{\circ}$ Edition, London: Routledge.

LEVITT, S. (1994), Using repeat challengers to estimate the effect of campaign spending on election outcomes in the House. Journal of Political Economy, 102: 77-98.

LIEBERMAN, E. (2005), Nested Analysis as a Mixed-Method Strategy for Comparative Research. American Political Science Review, 99, 3: 435452.

LIJPHART, A. (1971), Comparative politics and comparative method. American Political Science Review, 65, 3: 682-693.

MILYO, J. (1998), The Electoral Effects of Campaign Spending in House Elections: A Natural Experiment Approach. Working paper, 1998. Available at: http://ideas.repec.org/p/tuf/tuftec/9806.html

OWENS, J. and OLSON, E. (1997), Campaign Spending and the Electoral Process in California, 1966-1974. The Western Political Quarterly, 30, 4: 493-512. 
PALDA, K. (1973), Does Advertising Influence Votes? an Analysis of the 1966 and 1970 Quebec Elections. Canadian Journal of Political Science, 6: 638-55.

PALDA, K. (1975), The Effect of Expenditure on Political Success. Journal of Law and Economics, 18: 745-71.

PARTIN, R. (2002), Assessing the Impact of Campaign Spending in Governors' Races. Political Research Quarterly, 55, 1:213-233.

PATTERSON, S. (1982), Campaign Spending in Contests for Governor. The Western Political Quarterly, 35, 4: 457-477.

PEIXOTO, V. (2009), Financiamento de campanhas: o Brasil em perspectiva comparada. Perspectivas: Revista de Ciências Sociais, 35: 91116.

RAGIN, C. (1987), The Comparative Method: Moving Beyond Qualitative and Quantitative Strategies. Berkeley and Los Angeles: University of California Press.

SAMUELS, D. (2001a), Money, Elections and Democracy in Brazil. Latin American Politics and Society, 43(2): 27-48.

SAMUELS, D. (2001b), Does Money Matter? Campaign Finance in Newly Democratic Countries: Theory and Evidence from Brazil. Comparative Politics, 34: 23-42.

SAMUELS, D. (2001c), Incumbents and Challengers on a Level Playing Field: Assessing the Impact of Campaign Finance in Brazil. The Journal of Politics, 63(2): 569-584.

SHEPARD, L. (1977), Does Campaign Spending Really Matter? Public Opinion Quarterly, 41: 196-205.

SILBERMAN, J. and YOCHUM, G. (1978), The Role of Money in Determining Election Outcomes. Social Science Quarterly, 58: 671-82.

SMITH, B. (2001), Unfree Speech: The Folly of Campaign Finance Reform. Princeton University Press.

SWANSON, G. (1971), Framework for Comparative Research: Structural Anthropology and Theory of Action: Essay in Trends and Applications. Berkeley: University of University of California.

TUCKER, H. and WEBER, R. (1987), State Legislative Election Outcomes: Contextual Effects and Legislative Performance Effects. Legislative Studies Quarterly, 12, 4: 537-553.

WELCH, W. (1980), The Allocation of Political Monies: Economic Interest Groups. Public Choice, 35: 97-120.

WELCH, W. (1974), The Economics of Campaign Funds. Public Choice, 20: 83-97.

ZOVATTO, D. (2005), Financiamento de partidos e campanhas eleitorais na América Latina: uma análise comparada. Opinião Pública, 2, XI: 287-336. 


\section{APPENDIX}

Figure 16 - Correlation between raw and standardized measure of regulation

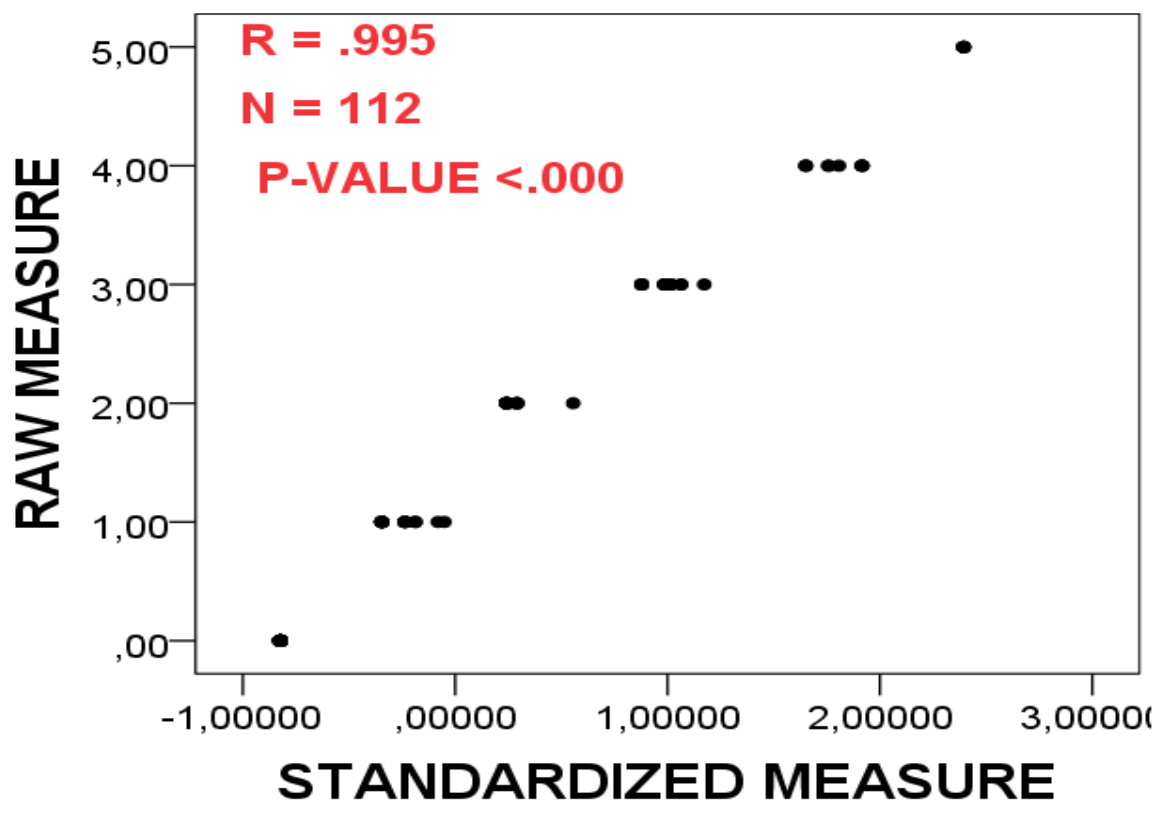

Figure 17 - Factor loadings of the standardized measure of regulation

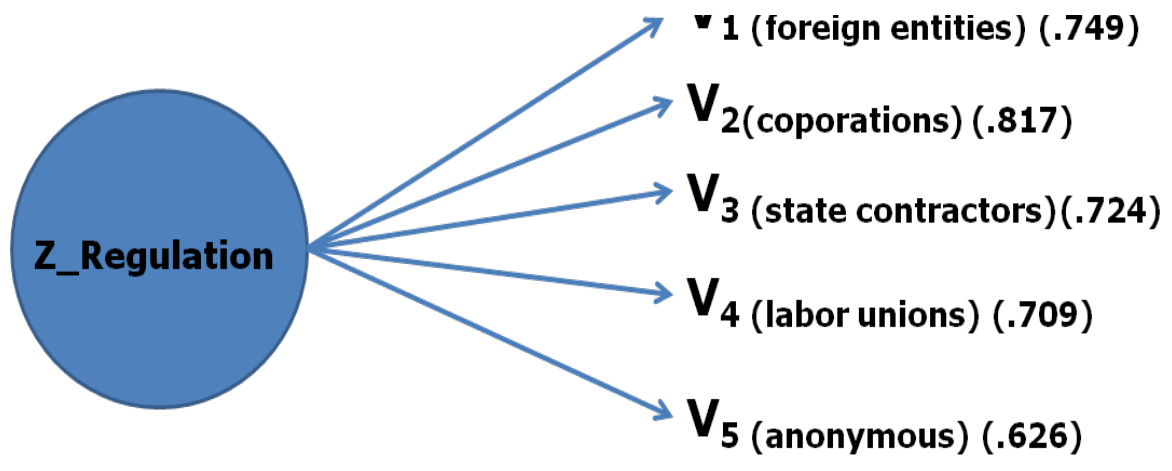

